\title{
VOKALNA TERAPIJA KOD TRANSRODNIH OSOBA
}

\author{
ANAMARIJA VARGA ${ }^{1}$, ANA BONETTI ${ }^{2}$ \\ ${ }^{1}$ Međimurska udruga za ranu intervenciju u djetinjstvu (MURID), Čakovec, ${ }^{2}$ Edukacijsko-rehabilitacijski fakultet, \\ Zagreb, kontakt: anamarija.varga91@gmail.com
}

Primljeno: 14.11.2015.

Stručni rad

Prihvaćeno: 29.1.2016.

UDK: 615.8

Sažetak: transrodne osobe su osobe koje osjećaju nesklad između roda s kojim se poistovjećuju i spola u kojem su se rodili. Transrodnost je širok pojam i obuhvaća čitav spektar rodno nenormativnih identiteta. Dva glavna obrasca tranzicije prema drugom spolu, odnosno rodu su: Male-to-Female (MtF) i Female-to-Male (FtM). Transrodne osobe navode da ih njihov glas često "izdaje”, odnosno otkriva njihov biološki rod te predstavlja posljednju prepreku u potpuno uživljavanje u novu rodnu ulogu. Bez obzira na to, često nisu svjesni da se zbog glasa mogu obratiti logopedu.

Cilj ovog preglednog rada je dati uvid u poremećaje glasa kod transrodnih osoba, odnosno opisati logopedsku procjenu te terapijske postupke, a sve u svrhu boljeg razumijevanja potreba ovih osoba.

Ključne riječi: transrodnost, vokalna terapija

\section{UVOD}

Transrodne osobe su osobe koje osjećaju nesklad između roda s kojim se poistovjećuju i spola koji im je pripisan pri rođenju (Unger, 2014). Transrodnost se često izjednačava s pojmom transpolnosti, no ova dva pojma nisu sinonimi. Pojam transpolnost se odnosi na osobe koje žele prilagoditi ili su već prilagodile svoje primarne $\mathrm{i} / \mathrm{ili}$ sekundarne spolne karakteristike feminizirajućim ili maskulinizirajućim medicinskim intervencijama (hormonima i/ili kirurgijom), najčešće uz permanentnu promjenu rodne uloge, dok se transrodnost odnosi na raznoliku skupinu ljudi koji prekoračuju ili nadilaze kulturno definirane kategorije roda. Rodni identitet transrodnih osoba u različitim stupnjevima se razlikuje od spola koji im je pripisan pri rođenju (Coleman i sur., 2012).

Poznato je da komunikacijski stil osobe može utjecati na to kako je druge osobe percipiraju i kakve su u interakciji s njom. To se pogotovo odnosi na transrodne, transpolne i rodno nenormativne osobe. Interpersonalna komunikacija je važan faktor koji utječe na društveno prihvaćanje i sliku o sebi transrodne osobe. Neke transrodne osobe smatraju da njihov glas izdaje njihovo pravo "ja", odnosno da je to zadnja prepreka na putu do izražavanja njihovog pravog roda (Christianson i Adler, 2006, prema Hancock i Garabedian, 2013).
Stoga transrodne osobe trebaju pomoć stručnjaka koji će im omogućiti da postignu glas koji neće otkriti njihov biološki rod (Pasricha i sur., 2008).

Prema Svjetskoj strukovnoj organizaciji za zdravlje transrodnih osoba (WPATH - The World Professional Association for Transgender Health, Inc.), glasovna i komunikacijska terapija može pridonijeti ublažavanju rodne disforije kao jedna pozitivna i poticajna etapa u postizanju ciljeva u rodnome izražavanju (Coleman i sur., 2012). Različita istraživanja potvrđuju važnost glasovne terapije za transrodne klijente, a potvrđuju da je"poklapanje govora i rodnog identiteta vrlo važno i kod trans-muškaraca (FtM - Female to Male) i kod trans-žena (MtF - Male to Female)" (Davies i Goldberg, 2006, str. 168). Feminizacija govora je široko prepoznata kao važan element u skrbi za transrodne osobe, dok kod maskulinizacije govora to nije slučaj (Davies i Goldberg, 2006). Postoje velike varijacije u željama transrodnih osoba u vezi s njihovim glasom. Neki žele maksimalnu feminizaciju ili maskulinizaciju, dok su drugi zadovoljni is androgenim stanjem. Neke osobe pak žele razviti dva uzorka govora (jedan više muški, drugi više ženski) zbog toga jer se smatraju bi-rodnim osobama ili zbog vanjskih pritisaka povezanih s obitelji, zaposlenjem, kulturnom okolinom ili zbog drugih poteškoća koje ih sprečavaju da cijelo vrijeme žive u skladu sa svojim identitetom (Davies i Goldberg, 2006). 
Transrodne osobe, dakle, nemaju poremećaj glasa u klasičnom smislu (npr.promuklost, hrapavost, vokalni noduli itd.). Njihov glas je u uobičajenim okvirima njihovog biološkog roda. Teškoća kod njih leži u tome što se taj glas ne poklapa s njihovim psihološkim, odnosno željenim rodom. Stoga se moraju koristiti atipične tehnike u terapiji i procjeni glasa (Adler, 2006, prema Hays, 2013).

Fokus ovog rada je na logopedskoj procjeni i terapiji glasa kod transrodnih i transpolnih osoba. Opisat će se postupak procjene koji započinje uzimanjem anamneze, a uključuje perceptivnu procjenu logopeda, samoprocjenu klijenta u koju spadaju i različiti upitnici te objektivnu analizu glasa. Nakon procjene će biti govora o terapiji, odnosno o ciljevima u terapiji te načinima provođenja terapije. Također će se spomenuti i razlike u terapiji između MtF i FtM klijenata.

\section{LOGOPEDSKA PROCJENA}

U svakoj procjeni primarno je određivanje kako pacijent trenutno koristi glas te koje su njegove glasovne mogućnosti. Također, već je prije spomenuto da, što se patologije glasa tiče, transrodne osobe ne moraju nužno imati poremećaj glasa. Njihov glas se jednostavno ne poklapa s njihovim rodnim identitetom. To svejedno ne znači da kod njih ne dolazi do neke patološke promjene na glasnicama. Važna je i samoprocjena pacijenta, odnosno kako on vidi svoj problem s glasom. Od velike važnosti je i pronalaženje primjerenih parametara i alata za procjenu, pogotovo zbog nastojanja znanstvenika za mogućnošću evaluacije učinkovitosti trenutnih standardnih tretmana feminizacije glasa te da se potencijalno prošire vidici o tome koji faktori utječu na percepciju ženstvenosti (Owen i Hancock, 2010).

Dok neke transrodne osobe traže pomoć logopeda zbog teškoća s telefonskim razgovorima ili lice-u-lice komunikacijom, druge dolaze zbog smanjivanja percipiranog nerazmjera između govora i identiteta. Procjena samo-percepcije se odnosi na to kako klijent percipira odnos između svojeg glasa i identiteta, odnosno, kako se klijent osjeća kad čuje sebe kako govori. Vrlo je važna dobra usklađenost, odnosno dobar odnos između govora i klijenta. Klijenti često imaju nerealistična očekivanja od terapije, stoga je potrebno odmah na početku razgovarati s njima o njihovim ciljevima. Pronalaženje dobrog odnosa između glasa i identiteta uključuje introspekciju klijenta i informirano mišljenje o tome što je moguće, a što nije u terapiji glasa (Davies i Goldberg, 2006).

\section{Uspostavljanje odnosa klijenta i logopeda}

Jedan od prvih koraka u procjeni je uspostavljanje povjerenja između logopeda i pacijenta. $\mathrm{Na}$ početnim seansama, osim što logoped procjenjuje pacijenta, i pacijent procjenjuje znanje i podršku logopeda (Davies i Goldberg, 2006). Odnos koji se temelji na međusobnom poštovanju, povjerenju i brizi za dobrobit pacijenta olakšava komunikaciju i potiče aktivno sudjelovanje u terapiji. Obrnuto, loš odnos može značajno utjecati na uspjeh terapije. Transrodne i transpolne osobe često imaju vrlo negativna iskustva s loše informiranim i pristranim zdravstvenim djelatnicima. Tijekom prvog susreta s klijentom, poželjno bi bilo da ga/nju logoped upita kojim imenom želi da ga/nju oslovljava, želi li da mu se obraća u muškom ili ženskom rodu, te ako je klijent zaposlen, kojim imenom želi da ga se oslovljava na poslu (vrlo važno ako je klijent u početnoj fazi tranzicije) (Gelfer, 1999).

\section{Anamneza}

Kod uzimanja anamneze, logoped mora dobiti informacije specifične za transrodnost kao i općenite informacije o klijentu koje mogu utjecati na opcije u terapiji i eventualne ishode. Prve informacije uključuju opću medicinsku povijest, gdje se logoped posebno mora usredotočiti na poteškoće s nosom i grlom, respiratorne bolesti, alergije, teškoće sa sluhom, poremećaje glasa (uključujući i probleme koji proizlaze iz toga da je osoba sama pokušavala promijeniti svoj glas) (De Bruin i sur., Soderpalm, 2004; prema Davies i Goldberg, 2006, Gelfer, 1999). Ove informacije nisu ništa drugačije od informacija koje logoped inače uzima od svojih klijenata. Ako klijenti imaju problema s gutanjem, promukli glas ili ostale simptome koji mogu upućivati na poremećaj glasa- zamor glasa, gubitak raspona glasa, neugodu u grlu- treba ih uputiti na ORL pregled (Davies i Goldberg, 2006). Također, logoped bi trebao znati o svim lijekovima koji se 
trenutno koriste (uključujući i hormone). Logopedu su potrebna i saznanja o korištenju supstanci koje negativno utječu na glas, poput pušenja i uživanja alkohola.

Osim negativnih ponašanja, logopedu su u procjeni važna i ponašanja koja mogu pozitivno utjecati na govor. Logoped bi trebao ispitati pacijenta o osobnom, profesionalnom ili rekreativnom korištenju glasa (npr.pjevanje ili gluma) kako bi odredio može li se prethodno vježbanje na neki način iskoristiti u terapiji. Treba se obratiti pažnja i na prethodne pokušaje feminizacije i maskulinizacije glasa, tehnike koje su se koristile, trajanje terapije (bilo da je sam klijent provodio te vježbe ili pod usmjeravanjem profesionalca) te klijentovo mišljenje o uspješnosti ishoda (Andrews, 1999, King i sur., 1999, Soderpalm i sur., 2004; prema Davies i Goldberg, 2006, Gelfer, 1999). Jedno od ključnih pitanja koje treba postaviti klijentu jest u kojoj fazi promjene spola se nalazi (Andrews, 1999, prema Gelfer, 1999). Važno je znati ide li klijent na savjetovanje zbog rodne disforije, je li počeo/la hormonsku terapiju te kada planira početi živjeti kao pripadnik/ca drugog spola (Gelfer, 1999). Logoped mora steći uvid u tretmane koji su na neki način utjecali na glas, poput testosteronske terapije kod trans-muškaraca (FtM) ili operacije feminizacije lica kod trans-žena (MtF). Nije potrebno osobu ispitivati o kirurškim i drugim postupcima koji ne utječu direktno na glas.

\section{Procjena govornih parametara povezanih $s$ rodom}

Temeljita procjena klijentovog glasa pruža osnovu na kojoj će se temeljiti terapija. Na temelju te početne procjene logoped može pratiti promjene u terapiji, a također može dobiti i informacije o tome od kojih promjena u glasu će klijent najviše profitirati. Kompletna procjena mora uključivati samoprocjenu glasa te akustičke i perceptivne metode (Davies i Goldberg, 2006). Logoped mora snimiti klijentov glas u različitim kontekstima- čitanju, opisivanju slike te u razgovoru. Ove snimke pomažu logopedu i klijentu u određivanju ciljeva u terapiji, analizi trenutnih uzoraka komunikacije te $u$ određivanju početne točke, odnosno osnove $u$ odnosu na koju će se mjeriti napredak u terapiji. Ako je dostupna tehnologija i ako se klijent osjeća dovoljno ugodno, logoped može napraviti videosnimku pomoću koje on i klijent mogu analizirati neverbalnu komunikaciju.

\section{Perceptivna procjena}

Perceptivna procjena je integrirani proces slušanja i opisivanja glasa (McNeill i sur., 2008). $\mathrm{Za}$ razliku od uobičajene perceptivne procjene glasa, gdje se sluša kvaliteta glasa, poput toga je li glas šuman, napet, hrapav i sl., kod procjene glasa transrodnih osoba, slušatelji najčešće ocjenjuju glas na ljestvici feminitet/maskulinitet te je li osoba koja govori muškarac ili žena. Naravno, obaveza logopeda je da procijeni i kvalitetu glasa. Najčešće se ocjenjivanje odvija na vizualno-analognoj skali- VAS, gdje se glas ocjenjuje na kontinuumu ženstvenosti (početna točka bi bila: Glas uopće nije ženstven, a završna: Jako ženstven). VA skale ocjenjivanja su jako bitne za procjenu glasa, kao i za evaluiranje učinkovitosti terapije. Owen i Hancock (2010) su u istraživanju dokazale da postoji značajna povezanost između fundamentalne frekvencije i ocjene ženstvenosti glasa, i od strane samog govornika i od strane slušatelja. U njihovom istraživanju je otkrivena i umjerena negativna korelacija između užeg raspona polutonova u govoru i percipirane ženstvenosti. To se zapravo kosi s prijašnjim istraživanjima koja izvještavaju o većoj varijabilnosti, odnosno većem rasponu osnovne frekvencije kod žena. No, treba napomenuti da se ovaj raspon odnosi na raspon polutonova u cijelom uzorku te se ne bavi obrascima infleksije u govoru. Nadalje, postoji visoka pozitivna korelacija između ocjene ženstvenosti glasa slušatelja i ocjena samih govornika što upućuje na to da slušatelji i govornici odgovaraju na iste perceptivne tragove kada ocjenjuju ženstvenost glasa. Umjerena pozitivna korelacija dobivena je između ocjene ženstvenosti glasa slušatelja i govornikove opće ocjene ženstvenosti što objašnjava ono što mnogi klijenti govore: "Glas je samo jedan od aspekata cijele osobe" (Owen i Hancock, 2010, str.282). Dakle, iako ovaj postupak pruža točne zaključke koji se odnose na percepciju slušatelja, njihove prosudbe ponekad uopće ne moraju biti povezane s tim "prolazi" li osoba kao žena u svakodnevnim interakcijama, gdje su bitan faktor različita verbalna i neverbalna ponašanja kao i izgled u skladu sa spolom (Dacakis, 2000). Ovo 
su u svom istraživanju potvrdili Van Borsel i sur. (2001). Van Borsel i sur. (2001) su otkrili da na procjenu spola/ženstvenosti slušatelja osim osnovne frekvencije, koja je najvažniji faktor u procjeni, utječu i drugi faktori. Čini se da su glas i fizički izgled osobe $\mathrm{u}$ interakciji kod procjene ženstvenosti kod MtF osoba. MtF osobe u njihovom istraživanju dobile su bolje ocjene na skali ženstvenosti na temelju fizičkog izgleda nego na temelju audiovizualne prezentacije (videosnimka) i bolje ocjene na temelju audiovizualnog prikaza nego na temelju audio prikaza (odnosno njihovog glasa). Rezultati sugeriraju da fizički izgled pozitivno utječe na percepciju ženstvenosti dok glas utječe negativno. Ove spoznaje se mogu iskoristiti u terapiji. Budući da fizički izgled pozitivno utječe na percepciju ženstvenosti glasa, dodatna pažnja na fizički izgled se čini korisnom, pogotovo u onim slučajevima gdje logopedska terapija nije bila naročito uspješna, a druge opcije (operacija) nisu moguće.

Van Borsel, De Pot i De Cuypere (2009) su pokušali otkriti jesu li glas i fizički izgled povezani i kod FtM osoba. Rezultati su drugačiji nego kod MtF osoba. Kao prvo, nema značajne korelacije između fundamentalne frekvencije i ocjena muževnosti. Također, na razini grupe nije bilo statistički značajnih razlika između tri načina prezentacije (vizualni, auditivni i audiovizualni) u ocjenjivanju muževnosti. Nije bilo ni statistički značajnih razlika između ocjena muževnosti i standardne devijacije fundamentalne frekvencije, što zapravo znači da je varijabilnost u intonaciji kod muškaraca mnogo manje važna nego kod žena. Čini se da fizički izgled postaje važan kad je glas visok, a manje važniji ako je glas nizak. Fizički izgled bi mogao biti važan u onim slučajevima kada hormonska terapija ne utječe na glas FtM pojedinaca.

\section{Klijentova subjektivna procjena}

Budući da su ciljevi klijenta izravno povezani sa samopercepcijom i osjećajima o percepciji drugih, važno je razumjeti perspektivu klijenta i očekivanja u oba ova područja (Andrews, 1999; Dacakis, 2002; Oates i Dacakis, 1997; Soderpalm i sur., 2004; prema Davies i Goldberg, 2006). Prijašnja istraživanja su pokazala da negativni i pristrani stavovi o transrodnim osobama utječu na to kako osoba vidi sebe (Hancock i sur., 2011). Ako osoba smatra svoj glas dovoljno ženstvenim, ta činjenica može poboljšati njezinu percepciju kvalitete života, ali ako ženstven glas dovodi do poremećaja glasa, općenita percepcija kvalitete života se može smanjiti zbog neugode povezane s glasom i/ ili zbog smanjene dopadljivosti glasa. Informacije o klijentovim osjećajima u vezi njegovog glasa mogu se dobiti polustrukturiranim intervjuom i/ ili formalnim mjerenjima poput standardiziranog upitnika. Ako logoped koristi polustrukturirani intervju, preporuča se da se koriste ista pitanja u pre- i post-evaluaciji.

Bez obzira na to koriste li se formalni ili neformalni alati za procjenu glasa, za logopede je korisno da zamole klijenta da ocijeni svoj identitet, ponašanje, izgled i govor na maskulinitet/feminitet te na muško/žensko ljestvici. Ovo logopedima pruža jasniju sliku klijentovog identiteta te im pomaže u raspravi oko klijentovih osjećaja o mogućem nerazmjeru između rodnog identiteta i rodnog izražavanja (Soderpalm i sur., 2004, prema Davies i Goldberg, 2006). Samoprocjena je osobito korisna kako bi se procijenilo zadovoljstvo glasom nakon terapije. McNeill i sur. (2008) su ustvrdili da klijentovo zadovoljstvo glasom nije nužno povezano s postignutom $\mathrm{F}_{0}$. Klijenti mogu relativno dobro procijeniti ženstvenost svog glasa. Subjektivna procjena klijentovog zadovoljstva je bolji pokazatelj uspjeha terapije od objektivnih mjera, a klijentovo zadovoljstvo njegovim glasom ne mora nužno korelirati s percepcijama logopeda ili neupućenih slušatelja (McNeill i sur., 2008).

Zabrinutost oko percepcije drugih je kod transrodnih osoba često povezana s " prolaznošću" (passability), odnosno percipiranja osobe od strane drugih kao muškarca ili žene. Želja da se "prođe" je složen osjećaj koji može biti pod utjecajem različitih faktora: klijentovog samo-definiranog roda; društvenih normi; vjerovanja i očekivanja obitelji, prijatelja, kolega na poslu, vršnjaka u zajednici i drugih koji su bliski s klijentom; internalizirane transfobije; stupnja društvene potpore; iskustva $\mathrm{s}$ lošim odnošenjem prema njemu/njoj (transrodne osobe se češće maltretira, zlostavlja i diskriminira) (Davies i Goldbreg, 2006). Budući da su norme povezane sa socijalnim interakcijama i govorom ovisne o kontekstu, važno je znati govorni kontekst koji klijentu stvara posebnu zabrinutost, 
poput zaposlenja ili socijalnih odnosa (BecklundFreidenberg, 2002, prema Davies i Goldberg, 2006). Kako klijent počinje mijenjati glas i govorne navike, treba raspravljati o reakcijama ljudi bliskih klijentu (Andrews, 1999; Dacakis, 2002; Oates i Dacakis, 1983; , prema Davies i Goldberg, 2006,Gelfer, 1999). Onim klijentima kojima je važno da "prođu" kao željen spol reakcije nepoznatih osoba su vrlo bitne i trebale bi se zabilježiti ili kao nekakva neformalna procjena ili u formalnom obliku (npr.dnevnik).

\section{Upitnici samoprocjene}

Standardni upitnici za samoprocjenu, odnosno procjenu klijenta o utjecaju poremećaja glasa na njegovu kvalitetu života su Indeks vokalnih teškoća (Voice Handicap Indeks - VHI) (Jacobson i sur., 1997), Voice Symptom Scale - VoiSS (Wilson i sur., 2004). T'Sjoen i sur. (2006) su pokušali VHI upitnikom odrediti kako kvaliteta glasa transrodnih osoba utječe na kvalitetu života te jesu li ti rezultati povezani s razinom steroidnih hormona. Ispitivali su MtF i FtM osobe. Osim standardnih 30 tvrdnji na tri podskale (emocionalnoj, fizičkoj i funkcionalnoj), istraživači su dodali jedno pitanje koje se odnosilo na to kako ih oslovljavaju ljudi kad ih zovu na telefon (on/ona). FtM osobe su ostvarile nizak rezultat, što upućuje na to da one smatraju da nemaju hendikep u glasu. Rezultati se mogu objasniti činjenicom da je zbog testosteronske terapije došlo do zadovoljavajućih promjena $\mathrm{u}$ glasu ispitanika. Kod MtF ispitanika rezultati su bili viši, ali i dalje nisu upućivali na invaliditet/ hendikep. Ovakvi rezultati su pokazali da upitnik VHI nije dovoljno osjetljiv za samoprocjenu glasa transrodnih osoba te da postoji potreba za stvaranjem specifičnog upitnika.

\section{Upitnik TSEQ}

Prvi upitnik kreiran specifično za transrodne osobe je razvila Shelagh Davies 2006. godine u British Columbii, Kanada (Dacakis i sur., 2013). Upitnik se zove Transgender Self-Evaluation Questionairre (TSEQ). TSEQ je osmišljen specifično kako bi izmjerio zabrinutost transseksualnih osoba za njihov glas i kako bi pružio široku sliku o iskustvu transseksualnih osoba s njihovim glasom i načinima na koje je glas povezan sa sviješću o sebi i sa svakodnevnim životom (Davies i Johnston, 2015). Istraživanje Hancock i sur. (2011) je pokazalo da TSEQ ima kriterijsku i test-retest valjanost, da postoji povezanost između rezultata na TSEQ upitniku i ocjena ženstvenosti i dopadljivosti glasa koje su davali govornici i naivni slušatelji. Što je rezultat na TSEQ veći, ocjene za ženstvenost i dopadljivost glasa su manje. Također, korelacija je veća za ocjene govornika nego za ocjene slušatelja. MtF osobe su povezivale percepciju ženstvenosti svog glasa s time koliko je njihov glas dopadljiv.

\section{Upitnik TVQ $\mathbf{Q}^{\mathrm{MtF}}$}

Upitnik TVQ ${ }^{\mathrm{MtF}}$ je također upitnik za samoprocjenu glasa kod trans žena čija je svrha kvantificiranje svakodnevnih doživljaja vezanih uz glas. Upitnik je do sada preveden na portugalski (Santos i sur., 2015), švedski, danski, njemački i hrvatski jezik (www.shelaghdavies.com/questionnaire/questionnaire.html).

Psihometrijska analiza upitnika $\mathrm{TVQ}^{\mathrm{MtF}}$ je autorima omogućila uvid u percepciju MtF osoba o njihovom vokalnom funkcioniranju te o utjecaju glasa na njihov svakodnevni život. Sudionici ispitivanja su se znatno razlikovali u svojim odgovorima. Ispitivanje je pokazalo da neki ispitanici rijetko ili nikada nemaju poteškoće s glasom, dok su kod drugih ispitanika te poteškoće mnogo češće (Dacakis i sur., 2013). Analiza je pokazala i značajnu negativnu korelaciju između vremena provedenog kao žena i ukupnog rezultataTVQ ${ }^{\mathrm{MtF}}$. Ovi rezultati se mogu objasniti time da su sudionici istraživanja s vremenom bili manje zabrinuti s time "da mijenjaju sebe kako bi zadovoljili potrebe društva za besprijekornom rodnom prezentacijom" (Byrne, 2007, prema Dacakis i sur., 2013). U istraživanju Dacakis i sur. (2013) najviše problema pojedincima zadaje psihosocijalni utjecaj glasa, i to ona tvrdnja koja se odnosi na uznemirenost zbog percipiranja osobe kao muškarca zbog njezinog glasa. Što se tiče vokalnog funkcioniranja, najviše poteškoća im zadaje niska visina glasa i velik trud i koncentracija kako bi proizveli željeni glas (Dacakis i sur., 2013). Ono što ohrabruje jest da polovica ispitanika ne doživljava ograničenja u svakodnevnom životu zbog svojeg glasa. Iznenađujući su rezultati na tvrdnji "Izbjegavam koristiti telefon zbog svojeg glasa”. Klijenti koji su 
na glasovnoj terapiji često izvještavaju o značajnom nezadovoljstvu kada razgovaraju na telefon. U ovom istraživanju to nije bio slučaj, no rezultati se mogu objasniti činjenicom da je tvrdnja formulirana tako da osobe pita o izbjegavanju telefona. Osobe možda ne izbjegavaju koristiti telefon, ali svejedno imaju poteškoća u komunikaciji preko telefona.

Osim te analize koja je ispitivala pouzdanost, Davies i Johnston (2015) su analizirale sadržajnu valjanost $\mathrm{TVQ}^{\mathrm{MtF}}$. Analiza je napravljena pomoću intervjua s pet žena, a koristila se kvalitativna metodologija dubinskog intervjua. Drugo pitanje u njihovom istraživanju se ticalo konkurentne valjanosti, odnosno autorice su postavile pitanje može li se iz odgovora na tvrdnje u $\mathrm{TVQ}^{\mathrm{MtF}}$ iščitati isti relativni stupanj zabrinutosti kao što se to vidi iz intervjua? Analiza je pokazala da, ukoliko je osoba tvrdnju označila većim brojem, vjerojatnije je da će više i opširnije raspravljati o toj temi u intervjuu (Davies i Johnston, 2015).

Autori također daju upute za što bolju primjenu upitnika te na što bi kliničari koji ga provode trebali obratiti posebnu pažnju. Kao i sa svim alatima za procjenu, učinkovito korištenje $\mathrm{TVQ}^{\mathrm{MtF}}$ se povećava s znanjem i iskustvom. Poznavanje psihosocijalne pozadine osobe koja ispunjava upitnik se također može pokazati korisnim. TVQ ${ }^{\mathrm{MtF}}$ je razvijen kako bi pomogao istraživačima, logopedima i transrodnim osobama u istraživanju glasa: kako je povezan s osjećajem rodnog identiteta i kako utječe na svakodnevno funkcioniranje u svijetu. Njihovo istraživanje je podastrlo dokaze da $\mathrm{TVQ}^{\mathrm{MtF}}$, ako se koristi promišljeno, može dati valjanu sliku o problemima s glasom koji muče transrodne žene (Davies i Johnston, 2015).

\section{Upitnik FCSQ}

Pasricha i sur. (2008) su također pokušali istražiti percepciju MtF osoba o njihovoj komunikaciji i zadovoljstvu komunikacijom u različitim situacijama i kontekstima. Intervjuirali su transrodne osobe, a od većih kategorija i tema koje su proizašle iz podataka iz intervjua, sastavljen je Functional Communication Satisfaction Questionairre (FCSQ). Analiza odgovora je pokazala da je najviše nezadovoljstva primijećeno kod komunikacije telefonom. Također, pokazalo se da emocije jako utječu na njihovu sposobnost zadržavanja ženskih komunikacijskih obrazaca. Ispitanicima je puno važnije da zadrže ženske komunikacijske obrasce tijekom razgovora sa strancima. Aspekt komunikacije kojim su najmanje zadovoljni je definitivno njihov glas. Naglasili su i važnost intonacije (Pasricha i sur., 2008).

Rezultati njihovog istraživanja su zapravo potvrdili koliko je, osim akustičke analize i perceptivne procjene, bitna i samoprocjena. Samoprocjena je bitna jer se iz nje može vidjeti i kvaliteta logopedske usluge (Pasricha i sur., 2008). FCSQ je upitnik koji istražuje situacije, kontekste, komunikacijske partnere i individualne aspekte komunikacije specifične za transrodnu populaciju. TCSQ također omogućuje logopedu uvid u klijentovu perspektivu kako bi pomogao poboljšati njegove/njezine sposobnosti u tim situacijama. (Pasricha i sur., 2008).

\section{OBJEKTIVNA PROCJENA}

\section{Visina glasa}

Visina glasa, odnosno fundamentalna frekvencija $\left(\mathrm{F}_{0}\right)$ je osnovni parametar pomoću kojeg se glas percipira kao muški ili ženski (Gunzburger, 1995; Van Borsel i Baeck, 2014). Normativni podaci za muški i ženski $\mathrm{F}_{0}$ se razlikuju od kulture do kulture i od jezika do jezika.

Visina fundamentalne frekvencije bi se trebala mjeriti posebnim programima za analizu govora $i$ to $u$ različitim zadacima.Također, podaci bi trebali biti izraženi i u Hz i u polutonovima kako bi olakšali kliničku evaluaciju.Vizualni prikaz bi se također trebao koristiti jer klijentu pruža vrijedne informacije o njegovoj/njezinoj habitualnoj visini glasa kao i o visini koja je cilj u terapiji, pogotovo u kontekstu diskusije o tipičnim muškim i ženskim rasponima visine glasa u klijentovom materinskom jeziku (Davies i Goldberg, 2006). Osim zabilježavanja osnovne frekvencije i raspona visine, važno je odrediti je li visina glasa viša (za MtF) ili niža (za FtM) u jednostavnijim zadacima poput čitanja nego npr. u spontanom razgovoru. Ako je zaista tako, moguće je da klijent već svjesno ili nesvjesno pokušava feminizirati ili maskulinizirati glas (Davies i Goldberg, 2006). Iako je visina glasa uvelike određena anatomijom larinksa i glasnica, postoje dokazi da na nju utječe i socijalni kontekst 
(Hasegawa i Hata, 1995, prema Davies i Goldberg, 2006). Stoga bi govornu visinu glasa bilo najbolje procijeniti u svakodnevnim situacijama koje su uobičajene za klijenta i s različitim konverzacijskim partnerima, no to je dosta nepraktično.

\section{Intonacija}

Intonacija se u engleskoj literaturi naziva još i infleksijom te se smatra vrlo važnom u percepciji roda, pogotovo kad je $\mathrm{F}_{0} \mathrm{u}$ "rodno neutralnom" rasponu preklapanja muških i ženskih normi (Becklund-Freidenberg, 2002; Spencer, 1988; Wolfe i sur., 1990; prema Davies i Goldberg, 2006, Gelfer i Scofield, 2000). Spomenuto je da se muškarci i žene razlikuju i u ovom parametru glasa (žene imaju više varijacija u intonaciji), ali ne postoje univerzalne norme za intonaciju žena $i$ za intonaciju muškaraca.

Obrasci intonacije bi se trebali snimiti u isto vrijeme kad i fundamentalna frekvencija. Vizualni prikaz snimke se zatim može pogledati zajedno s klijentom kako bi klijentu bilo lakše zapaziti obrasce intonacije povezane s rodom, naprimjer, dramatičan pad visine glasa na kraju rečenice je tipičan obrazac intonacije za muškarce, dok je veća varijacija tipičnija za ženske govornike engleskog jezika. Postoje li razlike između ženskih i muških govornika u intonaciji još nije dovoljno istraženo. Trans žene ponekad pokušavaju oponašati netransrodne žene tako da koriste pretjerane intonacijske pomake. Ako su ti pomaci prisutni, logoped treba klijentu ukazati na njih. Također je korisno procijeniti intonaciju tijekom govora. Kliničar može snimiti razgovor ili čitanje naglas i zatim zajedno s klijentom slušati vokalne infleksije te u raspravi koja slijedi nakon toga procijeniti točnost klijentovih percepcija (Davies i Goldberg, 2006).

\section{Rezonancija}

Postoje dokazi da frekvencije vokalskih formanata značajno utječu na to percipira li se osoba kao muškarac ili žena (Coleman, 1983; Mikos i Gelfer, 2001;Gelfer i Mikos, 2005; prema Davies i Goldberg, 2006). Uloga drugih tipova "rezonancije" je manje jasna. Pjevači se često referiraju na prsni registar kao na pun, bogat zvuk koji se proizvodi u donjim notama te je popraćen osjećajem vibriranja glasa u prsima te na čeoni registar koji se opisuje kao svjetliji zvuk koji je popraćen osjetima vibracija u ustima, nosu, sinusima ili gornjem dijelu glave. Dok neki autori govore da je kod govornika engleskog jezika prsni registar/rezonanca tipičan za muškarce, a registar glave uobičajeniji za žene, nema dokaza da povećanje subjektivnog osjećaja "registra glave" i smanjenje "prsnog registra" dovodi do povećane percepcije MtF osobe kao žene (Dacakis, 2002). Potrebna su dodatna istraživanja koja bi utvrdila utječe li vježbanje tih različitih registara na promjenu u frekvencijama formanata.

\section{Intenzitet glasa}

Norme za glasnoću (kod mikrofona udaljenog $30 \mathrm{~cm}$ od ustiju) su 68-76 dB za odrasle muškarce te $68-74 \mathrm{~dB}$ za odrasle žene. Uobičajen stereotip je da muškarci govore glasnije od žena, stoga neki logopedi uključuju i ovaj parametar glasa u procjenu i planiranje terapije. Moguće je da neke transrodne osobe počnu govoriti nedovoljnim intenzitetom glasa kako bi izbjegle pažnju javnosti, a neke MtF osobe govore tiše kako bi "omekšale" glas (Dacakis, 2002, prema Davies i Goldberg, 2006). To može rezultirati teškoćama u održavanju željenih obrazaca govora u situacijama gdje je potrebna veća glasnoća, poput govora u buci ili prenošenja intenzivnih emocija.

\section{Ostali parametri glasa}

Uzimajući u obzir ostale akustičke parametre za glas istraživanje King, Brown, McCrea, (2012) je pokazalo da vrijednosti frekvencijskih perturbacija (jittera) te amplitudnih perturbacija (shimmera) ne utječe na percepciju je li glas muški ili ženski. Istraživanje koje su proveli Klatt i Klatt (1990), analizirajući govorne rečenice 10 ženskih i 6 muških ispitanika je pokazalo da žene imaju više šumnu vokalnu kvalitetu od muškaraca.

\section{LOGOPEDSKA TERAPIJA}

Nakon što je obavio temeljitu procjenu, logoped može početi s terapijom. Kako bi pomogao klijentu i zajedno s njime postavio realne terapijske ciljeve, logoped bi trebao dati kratki sinopsis u kojem opisuje karakteristike klijentovog govora i glasa, fiziološka ograničenja i potencijal za promjenu te profesionalno mišljenje o parametrima glasa na koje 
bi se trebalo usmjeriti u terapiji. Mnoge transrodne osobe terapiju počinju s nerealističnim ciljevimažele ili previsoku $(\mathrm{MtF})$ ili prenisku $(\mathrm{FtM})$ visinu glasa, zato je potrebno odmah na početku odrediti realne ciljeve (Davies i Goldberg, 2006).

Neki klijenti su dobro upoznati s parametrima glasa povezanima sa spolom i terapijskim opcijama i dolaze na procjenu s jasnom idejom što žele. Drugi klijenti takvih znanja nemaju i očekuju smjernice logopeda. Važno je dobro procijeniti klijentovo znanje o govoru i glasu. Klijenti bi trebali biti dobro upoznati sa svim potencijalnim dobicima i rizicima (Davies i Goldberg, 2006).

Prosječna govorna visina, raspon visine, infleksije, frekvencija formanata, šumnost, artikulacija, pozicija jezika, facijalne ekspresije i geste mogu biti ciljevi u terapiji feminizacije ili maskulinizacije glasa. Specifični ciljevi u modifikaciji glasa ovise o tome što je izvedivo u proizvodnji bez naprezanja glasa te što se uklapa u klijentovu sliku o sebi. Neki klijenti se mogu osjećati ugodno s rodno neutralnim glasom, dok drugi žele glas koji slušatelji percipiraju ili kao muški ili kao ženski. Za klijente koji se žele uklopiti ili su zabrinuti zbog prihvaćanja, predlaže se da promatraju obrasce komunikacije u svojim socijalnim, kulturnim i radnim okolinama kako bi razvili kontekstualno specifični set normi (Oates i Dacakis, 1997, prema Davies i Goldberg, 2006). Također, korištenje glasa na nehabitualan način može dovesti do naprezanja. Održavanje učinkovitog i laganog glasa, uspostavljanje prikladnog vježbanja te informiranje klijenta o tome kako najbolje održavati zdravlje glasa su važni ciljevi u terapiji. Važno je i napomenuti da svaka terapija treba biti prilagođena potrebama svakog pojedinog pacijenta (Holmberg i sur., 2010).

Tradicionalno, logopedska terapija naglašava individualan način rada. No, kod rada sa specifičnim populacijama tipičan je i rad u grupama od četiri do šest osoba. Kod rada s transrodnim osobama korisni su i individualni i grupni rad.

Komponente logopedske terapije koje mogu dobro funkcionirati u grupi uključuju (Davies i Goldberg, 2006):

1. Edukacija i informacija

Klijenti trebaju razumjeti kako se glas proizvodi; kako fiziološke razlike u muškom i ženskom sistemu proizvodnje glasa utječu na glas i per- cepciju slušatelja; fiziološke i socijalne norme povezane s rodom i govorom; terapijske opcije, ishode i rizike; tehnike za prevenciju naprezanja povezanog s promjenom glasa.

2. Rasprava

Grupni rad je idealan jer članovi mogu dijeliti svoja zapažanja, uvide i praktične savjete.

3. Logopedske vježbe

Logopedske vježbe uključuju vježbe opuštanja, osnovne vježbe za učinkovitu vokalnu tehniku, i slušni trening (korištenje slušnih iskustava kako bi se izvježbala bolja percepcija razlika u govoru). Za one osobe koje se osjećaju samosvjesno tijekom govornih vježbi, sudjelovanje u grupi može imati normalizirajući efekt. Igranje uloga je također mnogo lakše u grupi, a promatranje drugih može mnogo pripomoći vlastitom vježbanju. Grupa pruža i sigurno okruženje za učenje vještina slušanja, kao i vježbanje govora koji neće biti nametljiv u okruženju stvarnog svijeta.

Nužna repetitivnost logopedskih vježbi se može obavljati u grupi tako dugo dok logoped može nadgledati napredak svih sudionika grupe i davati individualni input i povratnu informaciju.

Iako se logopedska terapija može raditi i kroz grupni rad, neke intervencije kao što su određivanje visine glasa, vježbanje ciljane visine, zahtijevaju individualan pristup logopeda (Davies i Goldberg, 2006). Iako terapijski protokoli moraju biti dovoljno fleksibilni kako bi se mogli odnositi na svaki od klijentovih ciljeva, fiziološki parametri i psihosocijalne potrebe se moraju zasnivati na trenutnom znanju najbolje kliničke prakse za govornu i glasovnu terapiju (Davies i Goldberg, 2006, str. 181).

Davies i Goldberg (2006) navode sljedeće protokole kao korisne u terapiji:

1. Imitacija ne-transrodnih osoba promatranih $\mathrm{u}$ svakodnevnom životu

2. Progresivno kompleksno vježbanje te istovremeno održavanje dobre kvalitete glasa

3. Vježbe za glasovnu fleksibilnost kako bi se održao raspon glasa i kvaliteta glasa

4. Motorički trening

5. Identificiranje i mijenjanje kvalitete glasa tijekom kašljanja, smijanja i pročišćavanja grla

6. Eksperimentiranje sa širokim rasponom vokalnih stilova 


\section{Terapija kod FtM osoba}

$\mathrm{Za}$ razliku od $\mathrm{MtF}$ osoba, relativno malo istraživanja se bavi glasom i glasovnom terapijom kod FtM osoba. Mali uzorci ispitanika, nedostatak detalja o metodama korištenima kako bi se promijenila prezentacija spola preko glasa, nemogućnost opisivanja metoda pregleda, govornih zadataka i normativnih vrijednosti značajno ograničavaju mogućnost uspoređivanja između različitih istraživanja i generalizaciju (Azul, 2015). Ovaj disbalans u literaturi zapravo reflektira široko rasprostranjenu pretpostavku među endokrinolozima i logopedima koja glasi da terapija testosteronom maskulinizira glas FtM osoba na isti način na koji testosteron maskulinizira glas adolescentskih bioloških muškaraca (Papp, 2011).

Većina postojećih istraživanja je vezana uz visinu glasa, ali pojavljuju se poteškoće jer često nedostaju akustički podaci, a i korišteni govorni zadaci nisu uvijek relevantni za svakodnevnu komunikaciju osobe. Važnost anatomskih dimenzija govornih organa kod trans-muškaraca kao i drugih glasovnih i komunikacijskih karakteristika osim visine se često spominju, ali ovi faktori nisu istraženi. Nadalje, ključni faktori koji zapravo određuju uspjeh osobe u njezinim nastojanjima da komunicira poput spola kojem pripada su također nedovoljno istraženi: samo-percepcija glasa, percepcija drugih ljudi, normativne vrijednosti korištene kako bi se procijenili različiti aspekti glasa transrodnih muškaraca (Azul, 2015). Jedino pitanje dovodi li korištenje testosterona do promjena u glasu je dosad više istraženo od ostalih. Iznenađujuće jest što nema kontroliranih istraživanja koja bi se bavila time kako hormonska terapija mijenja dimenzije vokalnih organa. Iako većina istraživanja izvještava o zadovoljstvu klijenata njihovom visinom glasa, nema dovoljno dokaza pomoću kojih bi se moglo zaključiti da je terapija testosteronom dovoljna kako bi transmuškarac bio prepoznat kao pripadnik željenog spola.

Potrebno je više istraživanja koja bi se bavila kompleksnim faktorima koji doprinose uspješnoj ili neuspješnoj komunikaciji kako bi se povećalo trenutno znanje o ovoj populaciji i omogućio pristup temeljen na dokazima kako bi ova raznolika populacija mogla dobiti specijaliziranu potporu. Iako se većina istraživanja bavi učincima testosterona na glas osoba, postoji mogućnost da neki transrodni muškarci žele na drugi način promijeniti svoj glas. Stoga bi se više istraživanja trebalo baviti koristima i ograničenjima logopedske terapije i operacije larinksa (Azul, 2015).

\section{Terapija kod MtF osoba}

Budući da MtF osobe imaju muški larinks, proizvode muški glas te iz toga proizlazi poremećaj glasa poznat pod nazivom rodna disfonija (de Bruin, Coerts i Greven, 2000, prema Hardy i sur., 2013). Najviše teškoća s percepcijom spola imaju u situacijama kada razgovaraju na telefon ili u komunikacijskim kontekstima koji ovise o auditivnom kanalu (Hancock i Garabedian, 2013). Te osobe često pokušavaju same promijeniti svoj glas primjenjivanjem nefizioloških tehnika poput šapta i hiperfunkcionalne fonacije bez pomoći stručne osobe (u ovom slučaju logopeda), što može dovesti do drugih poremećaja glasa. Ne treba zanemariti ni psihološku komponentu. MtF osobe često imaju negativne emocije o svojem glasu i mogu postati depresivne zbog svoje situacije, pogotovo ako još nisu počele proces tranzicije (Budge i sur., 2013, Coleman i sur., 2011, Dacakis i sur., 2013, prema Hardy i sur., 2013), stoga ih je potrebno što prije uključiti u logopedsku terapiju.

Većina MtF osoba koje žele modificirati svoj glas se odlučuju za klasičnu logopedsku terapiju, te obično ne idu na operaciju glasnica (Holmberg i sur., 2010). Postoje mnoga istraživanja koja potvrđuju efikasnost konzervativne, bihevioralne logopedske terapije. Aktivnosti u terapiji su ciljano usmjerene na potrebe svakog pacijenta (Hardy i sur., 2013).

Kod većine MtF klijenata, prvi i najvažniji cilj $\mathrm{u}$ terapiji glasa je postizanje osnovne frekvencije glasa iznad $160 \mathrm{~Hz}$. Ova frekvencija se najčešće navodi kao točka iznad koje se glas percipira kao ženski. Osim povećanja osnovne frekvencije, u terapiji cilj može biti i povećanje formanata. Mijenjanje oblika vokalnog trakta kod ustiju (tj. širenje usta) i mijenjanje gdje i u kojem omjeru se vokalni trakt sužava utječu na dužinu i oblik vokalnog trakta. To utječe na frekvencije formanata (Carew i sur., 2007). Prvi formant je veći ako 
je jezik postavljen niže, drugi formant je viši što se jezik više pomiče naprijed u ustima govornika, a viši treći formant je povezan s povećanim širenjem usta tijekom govora. Istraživanja (Gelfer i Scofield, 2000) upućuju na to da su karakteristike frekvencije formanata važni akustički tragovi u percipiranju spola.

Hancock i Garabedian (2013) su objavile retrospektivni pregled logopedskih terapija $25 \mathrm{MtF}$ osoba u razdoblju od 2006. do 2010. na GWUSHC-u (The George Washington University Speech and Hearing Center) u Washingtonu kako bi utvrdile koji su najčešći ciljevi u terapiji te postiže li klasična logopedska terapija zadovoljavajuće rezultate. Pacijenti su u prosjeku pohađali 22 terapijske seanse. Terapijski ciljevi su bili sljedeći: fonotraumatska ponašanja, vokalna higijena, tehnike opuštanja, fundamentalna frekvencija, intonacija, rezonancija, vokabular, pragmatika, neverbalna komunikacija i disanje. Fundamentalna frekvencija i rezonancija, koje se smatraju najvažnijim karakteristikama u percepciji spola, su bile najvažniji terapijski ciljevi u većini slučajeva. Pregled tih slučajeva naglašava važnost procjene rezonancije prije početka terapije. Autorice naglašavaju potrebu za primjenom upitnika za samoprocjenu na početku i na kraju terapije kako bi se nekako izmjerilo klijentovo zadovoljstvo. Važno je dokumentirati klijentovo zadovoljstvo radi evaluacije učinkovitosti terapijskih protokola za svaku osobu.

Mészáros i sur. (2005) su u svom istraživanju usporedili dvije skupine transrodnih osoba: 3 ispitanika koji su bili uključeni u logopedsku terapiju i 2 koja nisu. Ciljevi u terapiji bili su ženska visina glasa, smanjivanje laringealne mišićne napetosti, povećanje prsnog registra umjesto registra glave, proizvodnja blagih tonova, precizne artikulacije $i$ postignuće ženske intonacije te rad na stabilnosti fonacije (bez iznenadnih spuštanja u niske tonove). Terapija je u prosjeku trajala 9.6 mjeseci, a rezultati su sljedeći: porasla je fundamentalna frekvencija, Friedrichov indeks disfonije je bio blizu urednim vrijednostima. Glasovi su pokazali poboljšanja i u kvaliteti, habitualnoj govornoj visini i intenzitetu. Jedino što se smanjilo jest raspon visine glasa, što je normalno jer se podigla donja granica raspona visine. Kod ispitanika koji nisu bili uključeni u logopedsku terapiju došlo je do određenog povećanja osnovne frekvencije, no to povećanje je nastalo kao rezultat hiperfunkcionalne fonacije. Friedrichov indeks disfonije je i dalje nastavljao pokazivati patološke rezultate. Istraživanje je pokazalo pozitivne učinke klasične logopedske terapije, a autori naglašavaju i jednu veliku prednost konzervativne terapije- za razliku od operacije glasnica, ona nema nuspojava.

\section{ZAKLJUČAK}

S obzirom na njihove specifične potrebe, $u$ tretmanu transrodnih osoba bi trebao sudjelovati multidisciplinarni tim koji uključuje liječnika opće prakse, psihijatra, kirurga, endokrinologa. Jedan od stručnjaka koji bi također trebao biti uključen u proces rodne/spolne tranzicije je i logoped. Zašto logoped, odnosno terapija glasa i komunikacije? Zato jer je glas neizostavni dio čovjeka i njegovog identiteta. U slučaju transrodnih osoba glas koji se ne slaže s njihovim rodnim identitetom je često posljednja prepreka prema potpunom zadovoljstvu i uzrok diskriminacije i mnogobrojnih nedaća. Glas koji se poklapa sa slikom o sebi može smanjiti rodnu disforiju, poboljšati općenitu kvalitetu života te omogućiti osobi bolju integraciju i prihvaćanje društva.

Iako je očito zašto bi im trebala logopedska terapija, čini se da većina transrodnih osoba nisu svjesne da postoje stručnjaci koji bi im mogli pomoći. Najčešće ih liječnici koji ih tretiraju ne upućuju logopedima jer ni oni ne znaju da i ova vrsta terapije spada u opis posla logopeda. Isto tako, ni sami logopedi u većini slučajeva ne znaju da mogu biti dio tima koji će pomoći transrodnim osobama. Iz tog razloga nemaju ni potrebne dodatne kompetencije kako bi mogli pružiti usluge ovim klijentima. Organizacije poput WPATH-a također su tek nedavno u svoje Standarde skrbi uključile i glasovnu i komunikacijsku terapiju. S obzirom da je glas vrlo bitan dio ljudskog identiteta, a pogotovo identiteta transrodnih osoba, potrebno je dodatno podići svijest o glasovnoj i komunikacijskoj terapiji. Logopedi bi se trebali povezati s liječnicima kako bi oni uputili svoje pacijente koji su nezadovoljni svojim glasom na terapiju, a trebali bi se i dodatno educirati ukoliko misle raditi s ovom populacijom jer je kulturološka kompetentnost od strane stručnjaka vrlo bitna transrodnim osobama. 
Logopedsku terapiju najčešće trebaju MtF osobe, kod kojih hormonska terapija ne utječe na veličinu i masu glasnica, stoga se njihov glas ne mijenja. MtF osobe često same ili putem uputa $\mathrm{s}$ Youtubea pokušavaju promijeniti svoj glas. To najčešće rezultira velikom napetošću i neprirodnom, hiperfunkcionalnom fonacijom. Kao stručnjaci za glasovnu komunikaciju, logopedi u terapiji mogu pomoći MtF osobama kako da promijene svoj glas na prirodan način, bez nepotrebnog naprezanja glasa. Nema jedinstvenog protokola u logopedskoj terapiji za MtF osobe. Većina članaka i istraživanja objavljenih na tu temu izvještava da su osnovni ciljevi u terapiji povećanje fundamentalne frekvencije, povećanje frekvencije formanata te eventualno ženski obrasci intonacije i paralingvistički elementi. Također, većina logopeda obraća posebnu pažnju na vokalnu higijenu. Istraživanja se slažu da ciljanje samo jednog parametra glasa (npr. fundamentalne frekvencije) nije dovoljno da bi se glas percipirao kao ženski, tj.u terapiju je potrebno ukomponirati sve elemente. Primjećuje se i nedostatak istraživanja o dugoročnom uspjehu terapije. Također, veliki problem predstavljaju maleni i heterogeni uzorci ispitanika, kao i različiti zadaci koji se koriste $\mathrm{u}$ ispitivanjima. Ovi faktori značajno ograničavaju generalizaciju. Nedostaju i standardizirani upitnici za samoprocjenu koji bi procije- nili utjecaj glasa na kvalitetu života. Bez obzira na sve ove poteškoće, dosadašnji rezultati uglavnom potvrđuju uspješnost klasične bihevioralne terapije. Tek manji broj MtF pacijenata se odlučuje na operaciju glasnica, od kojih je najpoznatija krikotiroidna aproksimacija (CTA - Cricothyroid approximation). Operacija može podići fundamentalnu frekvenciju i feminizirati glas, ali bilo bi dobro kad bi to bila opcija tek ukoliko logopedska terapija ne uspije. Zahvat na glasnicama je invazivan, a fundamentalna frekvencija nakon nekog vremena ponovno opada.

Što se tiče FtM klijenata, za njih se pretpostavlja da u pravilu ne trebaju logopedsku terapiju jer terapija testosteronom spušta njihovu visinu glasa u okvire muškog raspona. No, novija istraživanja pokazuju da nije kod svih FtM osoba tako, stoga bi utjecaj testosterona na glas trebalo podrobnije istražiti.

Na kraju, može se zaključiti da polako dolazi do destigmatizacije transrodnih osoba u svijetu. Sve više stručnjaka je voljno raditi s njima i pomoći im. Jedni od tih stručnjaka su i logopedi. Korist od terapije glasa je višestruka. Može poboljšati kvalitetu života, a često predstavlja i premošćivanje posljednje prepreke na putu do svog pravog rodnog identiteta. 


\section{LITERATURA}

Azul, D. (2015): Transmasculine people's vocal situations:a critical review of gender-related discourses and empirical data, International Journal of Language and Communication Disorders, 50, 1, 31-47.

Carew, L., Dacakis, G., Oates, J. (2007): The Effectiveness of Oral Resonance Therapy on the Perception of Femininity of Voice in Male-to-Female Transsexuals, Journal of Voice, 21, 5, 591-603.

Coleman, E., Bockting, W., Botzer, M. i sur. (2012): Standardi skrbi za zdravlje transpolnih, transrodnih i rodno nenormativnih osoba (sedma verzija, službeni hrvatski prijevod), International Journal of Transgenderism, 13, 4, 165-232.

Dacakis, G. (2000): Long-Term Maintenance of Fundamental Frequency Increases in Male-to-Female Transsexuals, Journal of Voice, 14, 4, 549-556.

Dacakis, G. (2002). The role of voice therapy in transsexuals. Current Opinion in Otolaryngology and Head and Neck Surgery, 10, 173-177.

Dacakis, G., Davies, S., Oates, J.M., Douglas, J.M., Johnston, J.R., (2013): Development and Preliminary Evaluation of the Transssexual Voice Questionairre for Male-to-Female Transsexuals, Journal of Voice, 27, 3, 312-320.

Davies, S.M., Johnston, J.R. (2015): Exploring the Validity of the Transsexual Voice Questionnaire for Male-to-Female Transsexuals, Canadian Journal of Speech-Language Pathology and Audiology, 39, 1, 40-51.

Davies, S., Goldberg, J.M. (2006): Clinical Aspects of Transgender Speech Feminization and Masculinization, International Journal of Transgenderism, 9, 3-4, 167-196.

Gelfer, M.P. (1999): Voice Treatment for the Male-to-Female Transgendered Client, American Journal of SpeechLanguage Pathology, 8, 3, 201-208.

Gelfer, M.P., Scofield, K.J. (2000): Comparison of Acoustic and Perceptual Measures of Voice in Male-to-Female Transsexuals Perceived as Female Versus Those Perceived as Male, Journal of Voice, 14, 1, 22-33.

Gunzburger, D. (1995): Acoustic and Perceptual Implications of the Transsexual Voice, Archives of the Sexual Behaviour, 24, 3, 339-347

Hancock, A.B., Garabedian, L.M. (2013): Transgender voice and communication treatment: a retrospective chart review of 25 cases, International Journal of Language \& Communication Disorders, 48, 1, 54-65.

Hancock, A.B., Krissinger, J., Owen, K. (2011): Voice perceptions and Quality of Life of Transgender People, Journal of Voice, 25, 5, 553-558.

Hardy, T.L.D., Boliek, C.A., Wells, K., Rieger, J.M. (2013): The ICF and Male-to-Female Transsexual Communication, International Journal of Transgenderism, 14, 4, 196-208.

Hays, S.E. (2013): Attitudes about voice and voice therapy among transgender individuals. Magistarski rad. Louisiana State University and Agricultural and Mechanical College, Baton Rouge, Louisiana.

Holmberg, E.B., Oates, J., Dacakis, G., Grant, C. (2010): Phonetograms, Aerodynamic Measurements, Self-Evaluations, and Auditory Perceptual Ratings of Male-to-Female Transsexual Voice, Journal of Voice, 24, 5, 511-522.

Jacobson, B. H., Johnson, A., Grywalski, C., Silbergleit, A., Jacobson, G., Benninger, M. S., Newman, C. W. (1997). The Voice Handicap Index (VHI): Development and Validation. American Journal of Speech and Language Pathology, 6, 66-70.

King R.S., Brown G.R., McCrea C.R. (2012): Voice parameters that result in identification or misidentification of biological gender in male-to-female transgender veterans. Int J Transgenderism, 13(3), 117-130.

Klatt, D. \& Klatt, L. (1990). Analysis, synthesis, and perception of voice quality variations among female and male talkers. Journal of the Acoustical Society of America, 87, 820-857.

McNeill, E.J.M., Wilson, J.A., Clark, S., Deakin, J. (2008): Perception of Voice in the Transgender Client, Journal of Voice, 22, 6, 727-733. 
Mészáros, K., Csokonai Vitez, L., Szabolcs, I., Góth, M., Kovács, L., Görömbei, Z., Hacki, T. (2005): Efficacy of Conservative Voice Treatment in Male-to-Female Transsexuals, Folia Phoniatrica et Logopaedica, 57, 2, 111-118.

Owen, K., Hancock, A.B. (2010): The Role of Self- and Listener Perceptions of Femininity in Voice Therapy, International Journal of Transgenderism, 12, 4, 272-284.

Papp, V. (2011): A Female-to-Male transsexual voice: Physiology vs. preformance in production. Doktorska disertacija. Rice University, Houston, Texas.

Pasricha, N., Dacakis, G., Oates, J. (2008): Communicative satisfaction of male-to-female transsexuals, Logopedics Phoniatrics Vocology, 33, 1, 25-34.

T’Sjoen, G., Moerman, M., Van Borsel, J., Feyen, E., Rubens, R., Monstrey, S., Hoebeke, P., De Sutter, P., De Cuypere, G. (2006): Impact of Voice in Transsexuals, International Journal of Transgenderism, 9, 1, 1-7.

Unger, C.A. (2014): Care of the transgender patient: the role of the gynecologist,American Journal of Obstetrics and Gynecology, 210, 1, 16-26.

Van Borsel, J., Baeck, H. (2014): The Voice in Transsexuals, Revista de Logopedia, Foniatría y Audiología, 34, 1, 40-48.

Van Borsel, J., De Cuypere, G., Van den Berghe, H. (2001): Physical Appearance and Voice in Male-to-Female Transsexuals, Journal of Voice, 15, 4, 570-575.

Van Borsel, J., De Pot, K., De Cuypere, G. (2009):Voice and Physical Appearance in Female-to-Male Transsexuals, Journal of Voice, 23, 4, 494-497.

Wilson, J. A., Webb, A., Carding, P. N., Steen, I. N., MacKenzie, K., Deary I. J. (2004). The Voice Symptom Scale (VoiSS) and the Vocal Handicap Index (VHI): a comparison of structure and content. Clinical Otolaryngology, 29:2, 169-174.

www.shelaghdavies.com/questionnaire/questionnaire.html, pristupljeno mrežnoj stranici 2.11.2015.

\section{VOICE THERAPY FOR TRANSGENDER PEOPLE}

\footnotetext{
Abstract: transgender individuals are people who feel an incongruity between their self-identified gender and their birth gender. Transgenderism is a broad term and includes a spectrum of gender-nonconforming identities. The two main patterns of gender transition are Male-to-Female (MtF) and Female-to-Male (FtM).Transgender people often think their voice "betrays" them, i.e. it reveals their biological gender and represents the last obstacle to the individual's full enjoyment of his/her new gender role. Regardless of this, many transgender individuals are not aware of the fact that they can go to speech and language pathologists (SLP) for therapy.

The aim of this review article is to provide insight into the voice disorders of transgender people, i.e. to describe the assessment process and therapy protocols in hope of gaining a better understanding of the needs of this population.
}

Keywords: transgenderism, voice therapy 